\title{
透析患者の皮表角層インピーダンスの測定
}

\author{
筒井信博 沼田明古川敦子今川 章夫 \\ 中 北隆* \\ 高松赤十字病院腎センター 同皮膚科*
}

(昭和 63 年 11 月 8 日受付)

key words：透析患者，皮表角層インピーダンス，搔痒症，乾燥性皮膚症状

〈要旨〉

透析患者の搔痒症の原因の一つに皮膚の乾燥があげられているが，その程度を数量化した報告はない，乥こで, 逆 数が水分含有量を反映すると言われている皮表角層インピーダンスを健常人 39 名, 血液透析 (HD) 患者 37 名, 持続 的腹膜透析患者 (CAPD) 患者 11 名を対象に測定し, 透析患者の皮膚乾燥状態を測定する手法として有用かどうかに ついて検討した。インピーダンスの測定は SKICON-100 (IBS 社製)を用い, 手掌, 前腕屈側, 煩の 3 部位で行った.

手掌, 前腕屈側のインピーダンスは透析患者では健常人に比べ有意に大きく, 年齢との相関, 掻痒症状の有無で有 意差が認められたが, 透析期間との相関, 透析前後の变化, 疾患別での有意差は認められなかった.

以上により，透析患者では一般的に正常人に比べ皮膚乾燥が強く，皮表角層インピーダンスの測定は定量的に乾燥 状態を知る一つの方法として有用であると考えられた。

皮膚择痒症のある症例は皮表角層インピーダンスが有意に高かったが, インピーダンスが低くても皮膚搔痒症の強 い症例があり，透析患者の皮膚掻痒症は皮膚乾燥だけで説明できる病態とは考えられなかった。

今後, 皮膚掻痒症に対する各種治療法の前後に皮表角層インピーダンスを測定することにより，さらに皮膚掻痒症 の原因を解明する指標となりうると考えられた。

\section{Evaluation of impedance of the epidermal stratum corneum in dialysis patients}

Nobuhiro Tsutsui, Akira Numata, M. D., Atsuko Furukawa, M. D., Akio Imagawa, M. D. Takashi Nakakita, M. D.*

Kidney Center and Department of Dermatology, Takamatsu Red Cross Hospital.*

Although dry skin is believed to be a cause of pruritus in dialysis patients, no quantitative report has been made. We measured the impedance of the epidermal stratum corneum, impedance being inversely related to skin water content, in 39 healthy subjects, 37 hemodialysis (HD) patients, and 11 continuous ambulatory peritoneal dialysis (CAPD) patients, and afterwards considered regular adoption of this method for evaluation of the degree of skin dryness in dialysis patients. Using SKICON-100 (IBS Co.), impedance was measured at three sites ; the palm, flexor aspect of the forearm, and cheek.

The impedance of palm and flexor aspect of the forearm in dialysis patients was significantly higher than in healthy subjects. Furthermore, we found a significant correlation with age, and differences according to the presence or absence of pruritus. In contrast, there was no significant correlation with period of dialysis, changes before and after dialysis, or across different diseases.

The above results showed that dialysis patients generally had drier skin than healthy subjects, and that determination of the impedance of the epidermal stratum corneum was generally useful for quantitative evaluation of the degree of dryness.

A significantly higher impedance was seen in most cases with pruritus, although there were some cases with

筒井 信博 高松赤十字病院腎センター

于 760 高松市番町 4-1-3(0878-31-7101) severe pruritus that showed a low impedance. Threfore, dryness of the skin alone cannot completely explain the 
pruritus in dialysis patients.

In the future, determination of impedance of the epidermal stratum corneum, before and after treatment, will be considered one index for clarification of the cause of pruritus.

\section{緒言}

透析患者における皮膚症状のうち, 搔痒症は最も苦痛 を伴う自覚症状であり, その発生頻度は一般的に 50〜80\%と言われている ${ }^{1)}$. 掻痒症の原因としては副甲 状腺機能六進症, カルシウムやマグネシウム ${ }^{21}$ の代謝異 常, ヒスタミンの遊離など数多く取り上げられ, 皮膚の 乾燥もその一因として有力である. しかし, 皮膚の乾燥 は肉眼的に判断されており, 乾燥の程度を数量化した報 告はない.

皮表角層インピーダンスは逆数が水分含有量を反映す ると言われ ${ }^{3,4)}$, 既に各種皮膚疾患における測定について 報告がある. 本法が透析患者の搔痒症の皮膚乾燥状態を 反映し, 皮膚搔痒症の診断, 治療効果の判定などに有用 な検査法となりうるかどうかについて検討したので報告 する.

\section{対象および方法}

対象は血液透析 (HD) 患者 37 例 (男性 21 例, 女性 16 例), 持続的腹膜透析 (CAPD) 患者 11 例 (男性 6 例, 女 性 5 例) および健常人 39 例（男性 18 例, 女性 21 例) で ある. 年齢は $\mathrm{HD}$ 患者で $18 \sim 76$ 歳 (平均 $52.6 \pm 14.9$ 歳), CAPD 患者で $37 \sim 69$ 歳 (平均 $50.7 \pm 9.8$ 歳), 健常 人で $23 \sim 93$ 歳（平均 $46.2 \pm 20.4$ 歳）で 3 群間に有意差 はなかった.

これらの対象症例に $3.5 \mathrm{MHz}$ 高周波インピーダンス 測定装置（SKICON-100, IBS 社製）を用い, 手掌, 前 腕屈側, 煩の 3 部位で測定した. 測定は一人一部位につ き 9 回行い, 大小それぞれ 2 個のデー夕を削除し, 残り の 5 個のデータの平均を測定值とした.

なお，発汗の影響を除くため，室温 $20 \sim 22^{\circ} \mathrm{C}$, 相対湿 度 45〜55\%の環境下で測定した.

\section{結果}

手掌の皮表角層インピーダンスは HD 患者 $5.8 \sim 300.0$ $\mathrm{k} \Omega$ (平均 $105.5 \pm 70.6 \mathrm{k} \Omega$ ), CAPD 患者 $16.6 \sim 316.6 \mathrm{k} \Omega$ (平均 $142.2 \pm 82.1 \mathrm{k} \Omega$ ), 健常人 $1.6 \sim 333.3 \mathrm{k} \Omega$ (平均 48 . $0 \pm 80.4 \mathrm{k} \Omega)$ で, HD 患者 $(\mathrm{p}<0.01), \mathrm{CAPD}$ 患者 $(\mathrm{p}<$ 0.01）は健常人に比べ有意に大きかった.

同様に, 前腕屈側では $\mathrm{HD}$ 患者 $10.5 \sim 466.7 \mathrm{k} \Omega$ (平均 $119.0 \pm 105.7 \mathrm{k} \Omega$ ), CAPD 患者 $11.9 \sim 226.5 \mathrm{k} \Omega$ (平均 103 . $3 \pm 54.8 \mathrm{k} \Omega$ ), 健常人 $5.7 \sim 88.1 \mathrm{k} \Omega$ (平均 $29.0 \pm 16.7 \mathrm{k} \Omega$ ) で, HD 患者 $(\mathrm{p}<0.001)$, CAPD 患者 $(\mathrm{p}<0.001)$ は健常人に比べ有意に大きかった.

また，煩では HD 患者 $8.3 \sim 170.8 \mathrm{k} \Omega$ （平均 $51.5 \pm 36$.
表 1 皮表角層インピータ゚ンス $(\mathrm{k} \Omega)$

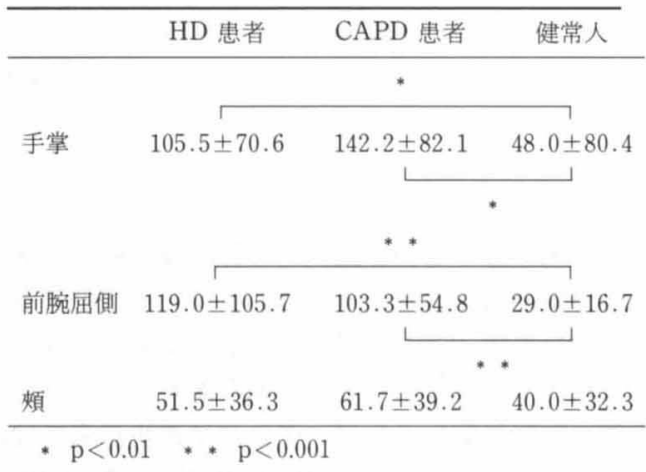

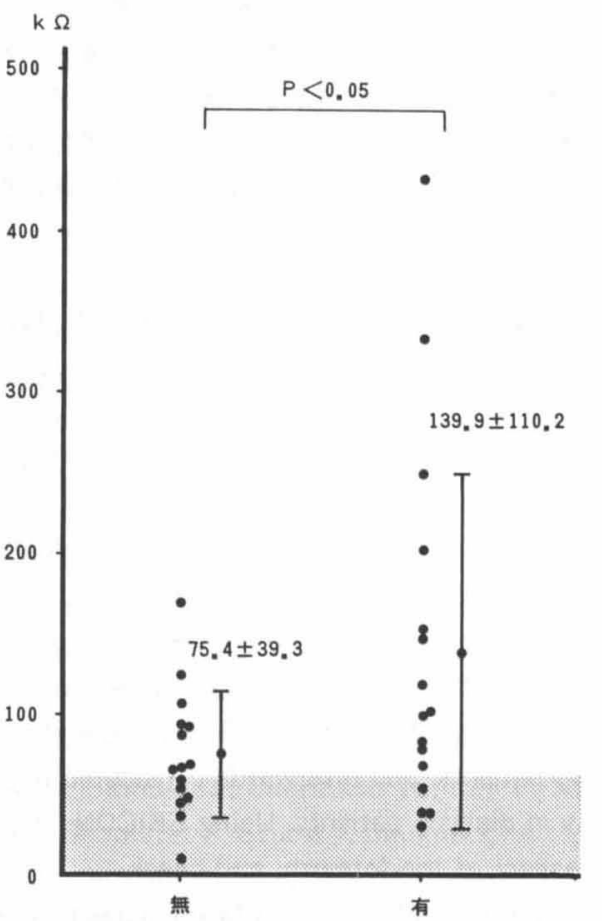

図 1 搔痒症状の有無での皮表角層インピーダン スの比較
$3 \mathrm{k} \Omega$ ), CAPD 患者 $17.9 \sim 140.6 \mathrm{k} \Omega$ (平均 $61.7 \pm 39.2$ $\mathrm{k} \Omega$ ), 健常人 $5.3 \sim 148.8 \mathrm{k} \Omega$ (平均 $40.0 \pm 32.3 \mathrm{k} \Omega$ ) で, HD 患者, CAPD 患者は健常人に比べ大きい傾向にあっ たが有意ではなかった，HD 患者と CAPD 患者の間に も有意差は認められなかった（表 1 ).

ついで, 前腕屈側での測定値を用いて以下の検討を 


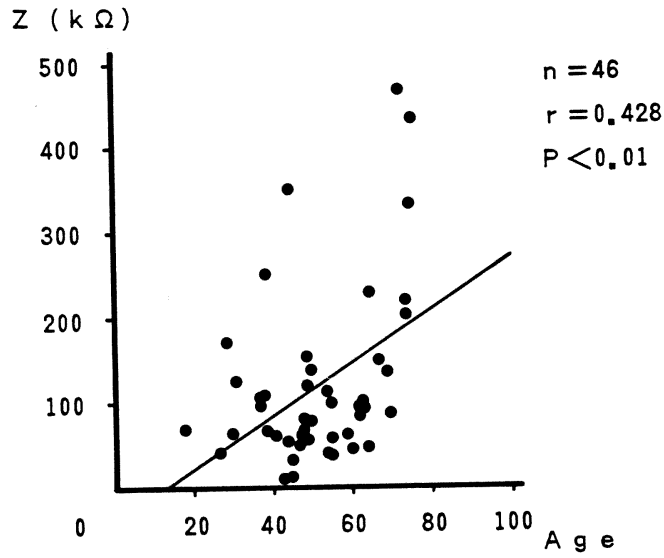

図 2 皮表角層インピーダンスと年齢の関係

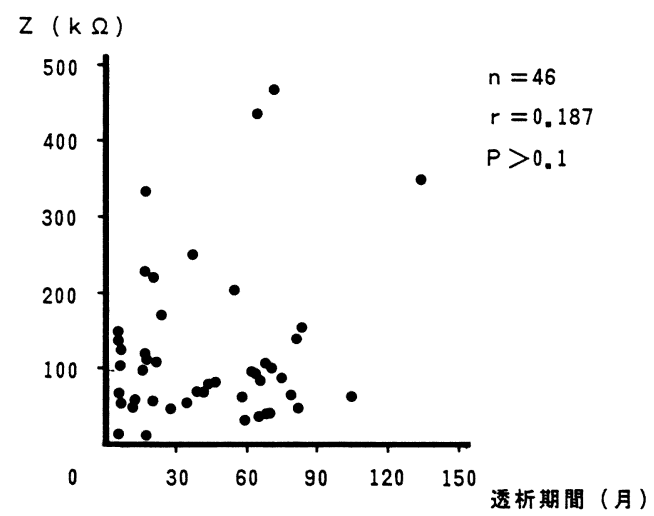

図 3 皮表角層インピーダンスと透析期間の関係

行った。

HD 患者において搔痒症状の有無で皮表角層インピー ダンスを比較すると, 搔痒症状のない群は $10.5 \sim 170.5$ $\mathrm{k} \Omega$ (平均 $75.4 \pm 39.3 \mathrm{k} \Omega$ ), 搔痒症状のある群は $31.8 \sim 433$. $3 \mathrm{k} \Omega$ (平均 $139.9 \pm 110.2 \mathrm{k} \Omega$ ) と, 搔痒症状のある群で有 意に大きかった $(\mathrm{p}<0.05)$.また, 健常人の平均值 $+2 \mathrm{SD}$ である $62.4 \mathrm{k} \Omega$ 以下を正常とみなすと, 搔痒症状のない 群では 15 名中 9 名が, 搔痒症状のある群では 16 名中 12 名が高値を示した（図 1 ）。

皮表角層インピーダンスと年齢の関係をみると，相関 係数 0.428 で有意の正の相関が認められた $(\mathrm{p}<0.01)$ (図 2 ).

皮表角層インピーダンスと透析期間の関係をみたが, 両者の間には有意の相関は認められなかった（図 3 ).

透析前後の皮表角層インピーダンスを比較してみる と, 透析前は $10.5 \sim 466.7 \mathrm{k} \Omega$ (平均 $119.0 \pm 105.7 \mathrm{k} \Omega$ ), 透析後は $4.8 \sim 433.3 \mathrm{k} \Omega$ (平均 $97.5 \pm 100.4 \mathrm{k} \Omega$ ) と有意差 は認められなかった（図 4 ).

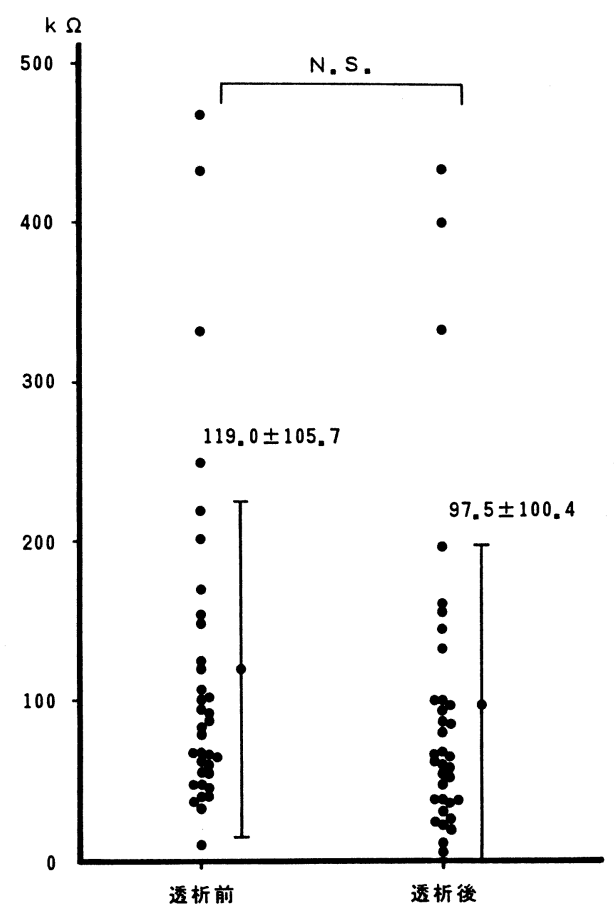

図 4 透析前後での皮表角層インピーダンスの 比較

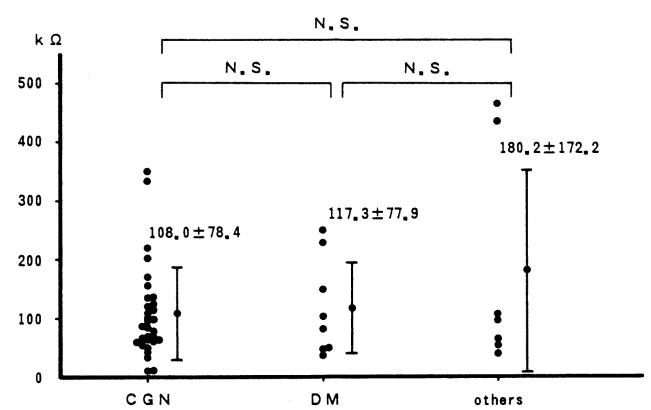

図 5 疾患別での皮表角層インピーダンスの比較

疾患別に皮表角層インピーダンスを比較してみると， 慢性系球体腎炎群は $10.5 \sim 350.0 \mathrm{k} \Omega$ (平均 $108.0 \pm 78.4$ $\mathrm{k} \Omega$ )，糖尿病性腎症群は $36.2 \sim 250.0 \mathrm{k} \Omega$ (平均 $117.3 \pm 77$. $9 \mathrm{k} \Omega$ )，その他の群は $39.9 \sim 466.7 \mathrm{k} \Omega$ (平均 $180.2 \pm 172$. $2 \mathrm{k} \Omega$ ) と 3 群間に有意差は認められなかった（図 5 ).

\section{考察}

インピーダンスの測定法には低周波を用いる方法と高 周波を用いる方法があるが，低周波法では乾燥した電極 を用いるとインピーダンスが高く出るので，電極と皮膚 の間に周囲の温度や湿度と同じ環境となる溶液を用いな ければならず，システムが非常に繁雑となる。一方，高 周波法では乾燥した電極で測定が可能であるので簡便で 
あるが, 皮膚角質層の表層数層のインピーダンスを測定

している可能性が示唆されている5).

最近は非常に低いインピーダンスを正確に測定できる 回路が開発されるなどの改良が進み ${ }^{6)}$, 高周波インピー ダンス法を用いて外用剤の保湿効果の評価 ${ }^{7)}$ 病的角層 における水分保持能の測定帛などが行われている.

今回使用した SKICON-100 は高周波インピーダンス 法による皮表角層インピーダンスの測定ができるが, 若 干, 安定性に乏しいので, 9 回の測定の高低 2 回ずつを 切り捨て, 残りの 5 回の測定值の平均をとることで安定 した測定值を得ることができた。

従来, 透析患者の皮膚の乾燥が搔痒症との関連で問題 とされていたが, 皮膚の乾燥度を数量化する方法として 皮表角層インピーダンスが有力な指標となるかどうかを 検討するのが今回の目的であった。

今回の検討の結果, 皮表角層インピーダンス值は健常 人に比べ透析患者で有意に大きく, さらに搔痒のない群 に比べある群で有意に大きかった。したがって, 他に皮 膚の乾燥状態を定量的に知る方法がないため比較はでき ないが, 皮膚の乾燥状態を十分に表現していると考えら れた。一方, 搔棒の有無にかかわらず一部の症例では皮 表角層インピーダンス值が重複しており，皮膚の乾燥は 搔痒の一因ではあるが，ほかにも多くの原因が関与して いることが示唆された。

現在, 透析患者の搔痒症の治療も暗中模索の状態であ り, 抗ヒスタミン剂の投与, 紫外線照射 ${ }^{9}$ など様々な方法 が試みられているが, 皮表角層インピーダンスの測定に より乾燥状態を定量できるので, 従来言われている乾燥 性皮膚症状を伴う搔痒症に, 入浴方法の改善などの日常 生活の指導や尿素外用剂塗布 ${ }^{10)}$ などの対症療法が有効で あるかどうかの検討にも本法は使用できるなど応用範囲 が広いと考えられ，今後検討する予定である.

\section{結語}

皮表角層インピーダンスについて検討し, 健常人に比 べ透析患者で有意に大きく, 加齢に伴って大きくなり, 搔痒症の有無で有意差が認められるが, 透析法の違い, 透析期間などとは関与しないことを報告した。本法は透
析患者の皮膚の乾燥状態を知る有力な検査法であり, 今 後, 透析患者の皮膚搔痒症の解析, 診断, 治療法の確立 などに有力な指標になると考えられた。

本論文の要旨は第 33 回日本透析療法学会総会で発表した.

\section{文献}

1）青野仁美, 宮島伸子, 紫田加代子, 三好幸子, 加藤 信一郎, 青木 正: 透析患者の搔症症に対する検討. 腎と透析 $20: 649-653,1986$

2) Gonella $M$ : Plasma and tissue levels of magnesium in chronically hemodialyzed patients: Effects of dialysate magnesium levels. Nephron $34: 141-145,1983$

3）田上八朗：角層の水分を測る。皮膚病診療 3 : 778-782, 1981

4）有間正敏, 定井正直: 各種界面活性剂による角質水 分変化. 香粧会誌 $5: 14-19,1981$

5) Leveque JL, Derigal J : Impedance methods for studying skin moisturization. J Soc Cosmet Chem $34: 419-428,1983$

6) Masuda $Y$, Nishikawa M, Ichijo B : New methods of measuring capacitance and resistance of very high loss materials at high frequencies. IEEE Trans Instrum Meas $29: 28-36,1980$

7）田上八朗：生体角層水負荷試験による外用剤の保湿 効果の評価法. 香粧会誌 $6: 100-106,1982$

8）吉国好道, 田上八朗, 井上邦雄, 白浜茂穂, 岩月啓, 奥 知三, 佐野 勉, 山田瑞穂: 病的角層に打ける 角層水分量, 水分保持能と経表皮的水分襄失の関係 について。.日皮会誌 $92: 1001-1003 ， 1982$

9）普天間新生, 大倉誉暢, 川原弘久, 三室信博, 石垣 繁博：透析患者の搔痒症に対する “Ultraviolet”療 法. 腎と透析 $7: 459-463,1979$

10）田上八朗, 大井正俊, 山田瑞穂: 尿素外用剤の皮膚 表面水分含有量に対する影響. 西日皮膚 42 : 647-652, 1980 